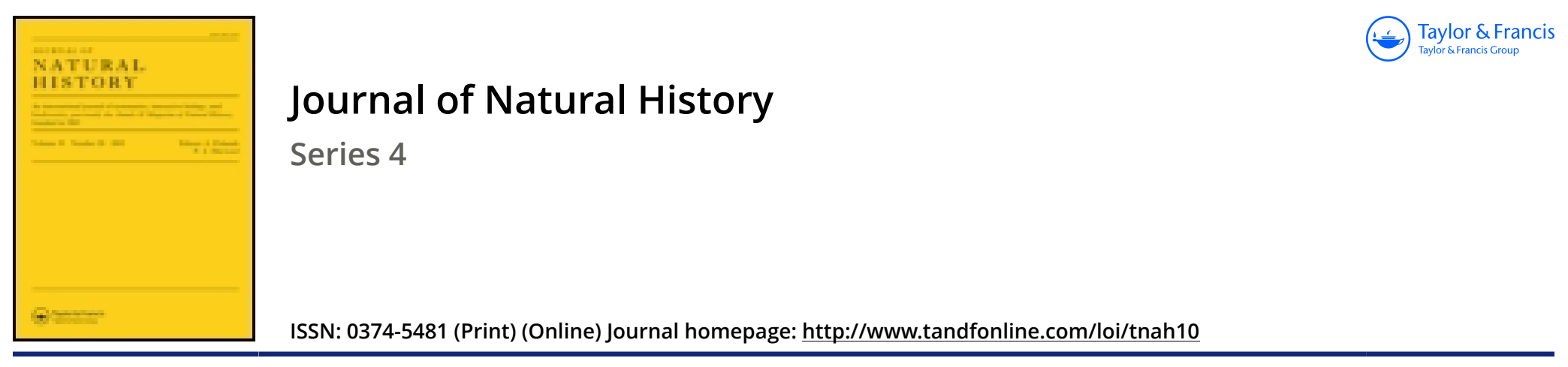

\title{
XII.-New species of Heterocerous Lepidoptera of the Tribe Bombyces, collected by Mr. W. B. Pryer chiefly in the District of Shanghai
}

\section{Frederic Moore F.Z.S.}

To cite this article: Frederic Moore F.Z.S. (1877) XII.—New species of Heterocerous Lepidoptera of the Tribe Bombyces, collected by Mr. W. B. Pryer chiefly in the District of Shanghai, Journal of Natural History, 20:116, 83-94, DOI: 10.1080/00222937708682201

To link to this article: https://doi.org/10.1080/00222937708682201

\section{曲 Published online: 13 Oct 2009.}

Submit your article to this journal $\pi$

Џ Article views: 6

4 Citing articles: 1 View citing articles 
Mr. Moseley also describes the slime-glands as "a series of elongate ramified tubes," while I describe them as a single branched tube. These glands in $P$. nove-zealandice are certainly very unlike Mr. Moseley's figure (pl. Ixxii. fig. 1). They may be different in the two species; but Mr. Moseley does not mention it when pointing out the differences between them.

In conclusion I wish to thank Mr. Moseley for his courtesy in telling me exactly what I saw, what I did not see, and what I imagined I saw ; but he will, I hope, excuse me if I still continue to use my own eyes in preference to looking through his.

Otago Museum, Dunedin, N.Z. $\mathrm{I}$ am, \&c., March 20, 1877.

XII.-New Species of Heterocerous Lepidoptera of the Tribe Bombyces, collected by $M r . W . B$. Pryer chiefly in the District of Shanghai. By Frederic Moore, F.Z.S.

\author{
Fam. Eggeriidæ.
}

Ageria howqua.

Wings hyaline ; anterior and posterior margins, apex, narrow discocellular band of fore wing, and veins of both wings black. Cilia cinereous brown. Body blue-black; collar and three narrow segmental bands on abdomen yellow, the bands on alternate segments from the base; anal tuft broad and slightly yellow-fringed. Palpi black above, white beneath. Body beneath streaked with white. Legs black; tibiæ and tarsi white-streaked.

Exp. $\frac{5}{8}$ inch.

Hab. Shanghai. In coll. W. B. Pryer.

\title{
Soronia, n. gen.
}

Fore wing long, narrow ; subcostal vein five-branched, first, second, and third arising before end of the cell, fourth and fifth beyond; cell long; discocellulars sinuous ; two radials; median vein two-branched, the branches short; submedian extending along hind margin. Hind wing long, trigonal, apex pointed, exterior margin very oblique, straight, anal angle rounded; subcostal vein two-branched; median vein threebranched, the branches arising together before end of the cell, discocellular straight; submedian and internal veins joined together near the base. Body short, stout, naked; abdomen pointed. Legs short; tibiæ thickly pilose above, armed with 
two pairs of spurs beneath. Antennæ slender, setaceous. Palpi rather long, slightly pilose.

\section{Soronia cuprealis.}

Fore wing dark cupreous; hind wing hyaline, slightly speckled with cupreous brown externally. Cilia fuliginous black. Body black; collar and band across thorax yellow. Abdomen with three yellow segmental bands, the upper near base, the two lower near apex; tip of abdomen beneath yellow, the two following segments banded with white. Palpi and streak on side of head white. Legs black above, white beneath. Antennæ black.

Exp. 1 inch.

Hab. Shanghai. In coll. W. B. Pryer.

\section{Melittia sangaica.}

Wings yellowish hyaline; fore wings with the borders, a narrow apical and a discocellular band, and the veins of both wings black; a short veinlet within the cell ; marginal border of hind wing narrowly lined with black. Base of fore wing and abdominal border yellow-speckled. Cilia blackish cinereous. Body purplish black; collar and thorax behind golden yellow; abdominal segments with narrow yellow band; abdomen beneath yellow. Antennæ black above. Palpi yellow, black-fringed ; fore legs yellow beneath, black above ; femora and tibiæ of mid legs clothed beneath with yellow hairs, above with black, ochreous, and a few white hairs; tarsi black; hind legs densely clothed with long hairs, black beneath, yellow above, and ochreous on outer side of tibiæ.

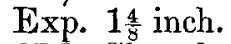

Hab. Shanghai. In coll. W. B. Pryer and F. Moore.

\section{Melittia longipes.}

Wings hyaline; fore wing with purplish black anterior and hind margins, apical band, broad patch at end of the cell, and veins of both wings; hind wing with slight cupreous brown outer margin and abdominal border. Cilia of both wings cinereous brown. Antennæ black above, speckled with lilacwhite. Body black; abdomen ochreous-speckled, segments with narrow lilac-white band. Front of thorax above with ochreous collar. Palpi white, fringed at tip with black. $\mathrm{Ab}-$ domen white. Fore and mid legs clothed above with short black and ochreous hairs, largely interspersed with white hairs; tarsi naked, black; hind legs very long, femora clothed with longish white hairs, and tibia with long tufted black 
hairs, interspersed above with a few ochreous red and white hairs ; tarsi clothed with very short tufted black hairs.

Exp. 1 inch.

Hab. Shanghai, In coll. W. B. Pryer and F. Moore,

\section{Fam. Agaristidæ.}

\section{Seudyra subflava.}

Upperside-fore wing with the apex and a broad band along hind margin dark chestnut-brown, washed with violet, the former traversed by a median longitudinal red-pointed black streak, and crossed by a whitish-speckled sinuous line; intermediate space from the base ochreous grey, profusely. speckled with dark brown, the veins grey-lined; a transverse subbasal and a double discal distorted recurved ochreous-grey line; a small orbicular and large reniform pale-bordered spot; a marginal row of black lunular spots: hind wing dark golden yellow, with a marginal golden-brown irregular-bordered band, which is broken at anal angle and ascends some distance upwards, the band traversed by a narrow yellow marginal lunular line; a small black spot in middle of cell; cilia grey. Thorax chestnut-brown, grey-speckled. Abdomen and legs golden yellow, with a short basal dorsal brown tuft. Underside pale golden yellow; both wings with a small black spot in the middle of the cell, and the fore wing with a larger spot at end of cell ; fore wing also with a pale narrow chestnut-brown decreasing band curving across outer margin from apex; hind wing with a much less distinct and smaller band.

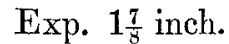

Hab. Snowy valley, Province Chekiang. In coll. W. B. Pryer.

This species is most nearly allied to $S$. venosa, from Darjiling, and may be distinguished by the entirely different underside.

\section{Fam. Zygænidæ.}

Pryeria, n. gen.

Fore wing long, narrow, apex produced, outer margin very oblique; costal vein moderately stout, extending to two thirds of the wing; subcostal slender, five-branched, first branch arising from before the end of the cell and terminating before the apex, second and fifth branches at end of cell, third and fourth very short, emitted from near end of second at apex; 
cell long, rather broad at its end; discocellular veins short, oblique, sinuous, emitting a recurrent discoidal veinlet, which extends within the cell to its base; two radials arising close together from upper discocellular; median vein running close to subcostal at base, three-branched at equal distances apart; a submedian and an internal vein curving from base to above posterior angle at equal distances apart between median and the outer margin, and joined together at their middle by a short transverse veinlet: hind wing short, somewhat oval; costa convex, apex acute; abdominal margin short; costal vein short, subcostal slender and extending to apex; cell broad; discocellulars long, sinuous; a discoidal veinlet emitted from angle of lower discocellular, and extending within to the end of the cell; median vein three-branched; submedian and internal veins joined together near base and extending to above posterior angle. Body short, densely pilose; abdomen with long apical tufted hairs. Antennæ broadly bipectinate, plumose. Legs long, slender; femora and tibiæ slightly pilose. Somewhat allied to Phauda, Walker.

\section{Pryeria sinica.}

Wings hyaline, fuliginous, sparsely covered with short, delicate, hair-like scales; base of fore wings tinged with golden yellow. Thorax with a few golden hairs on each side. Abdomen golden yellow, tuft black. Antennæ, thorax, and legs black.

Exp. 1 inch.

Hab. Shanghai. In coll. W. B. Pryer.

Fam. Chalcosiidæ.

\section{Erasmia sangaica, n. sp.}

Male. Black : fore wing with an ochreous-yellow, subbasal, transverse, oblique, irregularly sinuous band which is incurved hindward; an irregular oblique interrupted discal series of blue-bordered white spots, and two similar spots beyond nearer the apex; some metallic green and blue streaks at base of wing: hind wing with a round subapical and irregular median discal series of blue-bordered white spots; an indistinct ochreous spot near base of anterior margin ; abdominal margin broadly streaked with steel-blue. Thorax metallic blue; abdomen and legs greenish grey. Underside as above; ochreous spot on hind wing prominent.

Exp. $3 \frac{2}{8}$ inches.

$H a b$. Chinkang, near Shanghai. In coll. W. B. Pryer. 
Fam. Lithosiidæ.

\section{Lithosia alba.}

Male and female. Upperside pure silky white. Undersidefore wing cinereous brown, cilia white : hind wing as above. Antennæ and legs brownish cinereous.

Exp. 1 inch.

Hab. Shanghai. In coll. W. B. Pryer and F. Moore.

\section{Miltochrista decussata.}

Female. Yellow, palest on hind wing ; fore wing with two median transverse narrow black cross lines, small basal spots, a transverse discal sharply pointed sinuous line, and a submarginal parallel series of short streaks. Thorax spotted with black. Underside paler, base of costa and subapical streaks on both wings blackish. Legs with black bands.

Exp. $1_{\frac{1}{2}}^{\frac{1}{2}}$ inch.

Hab. Shanghai. In coll. W. B. Pryer.

\section{Miltochrista sinica.}

Pale ochreous red, palest on hind wing; fore wing with a narrow transverse median nearly straight blackish line, some spots at base, and longitudinal short discal streaks, one being on each vein, a spot at end of cell, and a marginal row of spots. A black spot on each side of thorax. Underside paler, markings indistinct. Legs streaked with black.

Exp. $\frac{6}{8}$ inch.

$H a b$. Shanghai. In coll. W. B. Pryer and F. Moore.

Setina albosericea.

Female. Silky yellowish white, costal edge and cilia yellow : fore wing with a black spot at the base, two median transverse oblique series, and a marginal series of black spots : hind wing with two less distinct black spots at apex. Thorax, head, antennæ, legs, and abdomen beneath yellow; thorax and abdomen above whitish; two black spots on middle of thorax. Underside pale yellow, spots indistinct.

Exp. $1_{8}^{3}$ inch.

Hab. Shanghai. In coll. W. B. Pryer.

\section{Setinochroa sanguinea.}

Fore wing dark vermilion-red, edge of costa and outer margin lined with black; a submarginal series of black spots; cilia brown : hind wing reddish black, with basal and margi- 
nal red streaks; abdomen blackish above; antennæ, spot on vertex, and legs blackish. Underside red, margins and apical streaks only black.

Exp. $\frac{7}{10}$ inch.

Hab. Shanghai. In coll. W. B. Pryer and F. Moore.

Fam. Arctiidæ.

Spilosoma mandarina.

Male. Upperside deep buff colour: fore wing with an oblique discal continuous linear series of small black veindivided narrow spots, and a short median submarginal series of smaller similar spots; a small dot near base of submedian vein: hind wing suffused with red on abdominal border; with two vein-divided prominent black spots near anal angle, a small dot near apex, and a prominent rounded spot at end of cell. Abdomen above crimson, with dorsal and two lateral rows of black spots. Underside slightly suffused with red on base of fore wing ; markings as above, but more prominent; also a large black cell-spot on fore wing. Antennæ, front of head, sides of thorax, palpi at tip, pectus, and legs above black. Palpi at sides, fore femora, and tuft at sides of thorax beneath crimson.

Exp. $2 \frac{2}{10}$ inches.

Hab. Shanghai. In coll. W. B. Pryer and F. Moore.

\section{Spitosoma howqua.}

Upperside pale buff-colour. Male: Fore wing with an oblique lower discal series of black spots, each spot crossed by a vein, a spot near base of hind margin, and an upper submarginal series of smaller spots: hind wing with a submarginal series of four larger vein-divided black spots, and a smaller spot at the end of the cell. Abdomen above red, with indistinct dorsal and two lateral rows of black spots; a blackish stripe down middle of thorax. Underside paler, markings as'above but more confluent; fore wing tinged with ochreons red along anterior margin; a small black spot at end of cell, tuft at base of wing and a short streak on hind margin near the angle. Antennæ, front of head, tip of palpi, tibiæ, and tarsi black; pectus dark brown; fore and mid coxæ and femora, and sides of palpi at base red.

Female with markings on upperside of fore wing less distinct; on hind wing as in male. Underside as in the male, excepting that the spot at end of cells is larger and the tuft obsolete at base of fore wing. 
Exp. $\delta 1 \frac{4}{8}$, q $1 \frac{6}{8}$ inch.

Hab. Shanghai. In coll. W. B. Pryer and F. Moore.

\section{Spitosoma erubescens.}

Female. Upperside pale pinky buff-colour; fore wing with two small black spots from hind margin near the angle; hind wing buff-white, broadly suffused with pale crimson on abdominal border. Abdomen above crimson, with dorsal and a lateral row of black spots. Underside-fore wing whitish on hind margin, base of costa and middle of wing suffused with crimson; an indistinct median discal oblique series of dusky spots, and a small spot at end of cell: hind wing broadly suffused with crimson on abdominal border and narrowly along base of anterior margin ; a small indistinct dusky spot at end of cell. Front of head, palpi at tip, and pectus dark brown. Antennæ, fore and mid legs above, and spots on hind legs black; femora of all the legs, and tuft at side of thorax beneath, crimson.

Exp. $1 \frac{6}{8}$ inch.

Hab. Shanghai. In coll. W. B. Pryer.

\section{Alpenus flammeolus.}

Female. Upperside pale purple-tinged ochreous red; edge of anterior margin and cilia of both wings yellow: fore wing with two median transverse recurved series of brown spots with pale borders, a single similar spot at upper end of cell, two indistinct spots below the apex and one near posterior angle : hind wing with a pale divided spot at end of cell. A dorsal series of small black spots on abdomen. Underside paler; fore wing showing only the cell-spot, the two spots below the apex, and the hind wing a prominent cell-spot and an indistinct spot near outer margin between the lower median and submedian veins. Front of head, palpi, legs, and body beneath yellowish. Antenne, tip of palpi, and streaks on fore and middle legs above brown.

Exp. 14 inch.

Hab. Snowy valley, Province Chekiang. In coll. W. B. Pryer.

\section{Fam. Notodontidæ.}

\section{Cerura menciana.}

Upperside-fore wing fuliginous grey, veins black; two small black spots at the base, an angular transverse subbasal series of spots, followed by a contiguous transverse tortuous 
double line, which is twice broken at its costal end; a discal series of longitudinal, elongated, double dentate lines; a marginal row of narrow streaks (one being between each vein): hind wing cinereous white, veins black; a blackish streak crossing end of cell, and a marginal row of prominent black spots. Thorax grey, spotted with black; abdomen above and a lateral row of spots black, beneath and tip above white. Underside cinereous white, veins blackish; markings on fore wings indistinct.

Exp. o $2 \frac{1}{3}, q 2 \frac{6}{5}$ inches.

Hab. Shanghai. In coll. W. B. Pryer and F. Moore.

Allied to C. erminea. Differs in having narrower and longer wings, sharper dentate markings between the veins, and more prominent basal spots.

\section{Cerura sangaica.}

Upperside pale vinous grey: fore wing with a broad subbasal transverse black-speckled band, bordered by ochreous speckles, and preceded by a basal row of black dots; a paler but similar band across the disk, a marginal row of black round spots : hind wing with a marginal row of black round spots, and an indistinct spot at end of cell. Body with greyish black bands. Underside as above, but paler.

Exp. 15 inch.

Hab. Shanghai. In coll. W. B. Pryer.

Most nearly allied to the North-American $C$. cinerea.

\section{Stauropus basalis.}

Upperside pale greyish brown; base of both wings greyish ochreous, divided on the fore wing by a transverse discal bent line; this wing also has a slight narrow streak at end of cell, a submarginal and marginal rows of grey-speckled black points: hind wing with a blackish marginal line. Underside as above, except that the base is paler; abdomen beneath and legs below whitish.

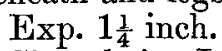

Shanghai. In coll. W. B. Pryer.

\section{Phalera flavescens.}

Phalera flarescens, Brem. \& Grey, Lep. Nord-China, p. 14 (1853).

Male. Upperside whitish testaceous: fore wing with a large basal, duplex, silvery grey and black spot divided transversely by a red ochreous bar; four similar-shaped spots of the same colour ascending outer margin from posterior angle, the former spot having the grey portion towards base of wing, the latter 
series towards outer margin; two indistinct lunular wavy yellow lines ascending towards costa from middle of hind margin : hind wing yellowish at base; an indistinct brownish recurved fascia from anal angle. Abdomen ochreous yellow. Antennæ, palpi at sides, and fore legs above brownish. Underside pale glossy whitish testaceous.

Exp. 2 inches.

Hab. Shanghai. In coll. W. B. Pryer.

\section{Lophopteryx sinensis.}

Upperside dark umber-brown: fore wing slightly blackspeckled, crossed by blackish sinuous subbasal and discal bands; a pale greyish streak obliquely from lobe of hind margin and speckles along the outer veins : hind wing with a short black-and-grey-speckled streak at anal angle. Underside pale brown.

Exp. o $1 \frac{2}{8}$, o $1 \frac{3}{8}$ inch.

Shanghai. In coll. W. B. Pryer and F. Moore.

\section{Ceira straminea.}

Male and female. Upperside-fore wing pale straw-yellow, indistinctly speckled with darker yellow at the base; an oblique discal transverse series of brown points terminating: at apex, where they are partly confluent; a marginal row of similar points; hind wing whitish cinereous. Body yellow. Legs brown above, yellow beneath. Underside pale strawyellow; fore wing in the male brownish cinereous in the middle.

Exp. 17 inch.

Hab. Japan. In coll. W. B. Pryer and F. Moore.

\section{Pterostoma sinica.}

Male. Upperside-fore wing pale dull testaceous, with slightly darker narrow longitudinal streaks between the veins; a median series of short chestnut-brown streaks, a submarginal and marginal sinuous line of same colour; inner lobe of hind margin black-and-grey fringed: hind wing brown. Body pale testaceous; abdomen with brownish dorsal tufts. Underside pale testaceous : fore wing longitudinally clouded with brown: hind wing with two outer series of short longitudinal brown streaks between the veins; a narrow marginal brown line and a clavate spot at end of cell.

Exp. $2 \frac{2}{8}$ inches.

Hab. Shanghai. In coll. W. B. Pryer.

Allied to P. grisea, Brem. et Grey, from the Amur Land. 


\section{Fam. Liparidæ.}

\section{Pantana sinica.}

Male greyish white: fore wing with the base, anterior and outer margins broadly bordered with fuliginous brown; a black-speckled irregular-shaped spot between the veins beneath the cell. Thorax fuliginous brown; front of head and palpi ochreous yellow. Abdomen and legs greyish white. Pectinations of antennæ dark brown, shafts grey.

Exp. 12 inch.

Hab. Shanghai. In coll. W. B. Pryer and F. Moore.

Near to P. baswara of Java, but smaller, the hind border of fore wing unmarked, and the hind wing without any marginal brown border.

\section{Loclia sangaica.}

Male. Upperside pale greyish ochreous, whitish ochreous at base of hind wing; fore wing with a short series of six black dots curving hindward from the apex; base of thorax and abdomen whitish. Pectinations of antennæ fuliginous, shaft whitish; front of head, palpi, and legs brownish ochreous. Underside paler, without spots.

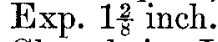

Shanghai. In coll. W. B. Pryer.

This species is closely allied to $L$. conosa and to L. sinensis, Walk.

\section{Redoa alba.}

Female. Pure white throughout: wings covered with glossy silky scales, which are disposed on the fore wings in numerous slightly raised transverse folds; a small black-speckled oblique spot at end of cell in fore wing.

Exp. $1 \frac{3}{8}$ inch.

Hab. Shanghai. In coll. W. B. Pryer.

The wings in this species are broader than in $R$. sinensis, and differ in the corrugated character of the fore wing.

\section{Redoa sinensis.}

Male and female. Pure white; wings covered with glossy silky scales; fore wing with an indistinct blackish-speckled spot at end of the cell. Front of head, palpi, bands on femora and tarsi ochreous yellow. Pectinations of antennæ pale brown.

Exp. o 1 $\frac{2}{10}$, ₹ $1 \frac{3}{10}$ inch.

Hab. Shanghai. In coll. W. B. Pryer and F. Moore. 


\section{Fam. Limacodidæ.}

\section{Parasa tessellata.}

Male. Upperside--fore wing with a broad median transverse green band, the outer margin of which is bordered by a brown wavy line; the base of wing obliquely vinous brown, outer border yellow, tessellated with brown speckles, and bordered by a narrow brown cilial line and edge: hind wing yellow; edge of cilia brown. Thorax and front of head green; abdomen ochreous yellow. Antennæ, palpi, and legs brown. Underside pale dull greenish yellow, borders brownish. Nearest to $P$. consocia, Walk.

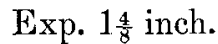

Hab. Shanghai. In coll. W. B. Pryer.

Parasa sinica.

Male and female. Upperside-fore wing with a median transverse green band, a large spot at base of costa and broad outer marginal band dark greyish brown: hind wing cinereous; edge of cilia at anal angle dark greyish brown. Thorax and top of head green; abdomen cinereous. Front of head, palpi, and legs brown. Underside greenish cinereous, edge of cilia brown. Near to P. hilaris, Westw.

Exp. $\frac{9}{10}$ inch.

Hab. Shanghai. In coll. W. B. Pryer and F. Moore.

\section{Miresa pallivitta.}

Male and female. Upperside-fore wing bright ochreous brown, greyish externally; a narrow whitish line obliquely from apex to middle of hind margin; hind wing cinereous brown. Cilia darker. Underside pale brown. Near $M$. nararia.

Exp. $\frac{7}{8}$ inch.

Hab. Shanghai. In coll. W. B. Pryer and F. Moore.

Setora sinensis.

Male. Upperside dark umber-brown: fore wing with a median greyish brown band, narrow on the costa and very broad on hind margin; outer margin slightly glossy brown. Front of head, thorax, and legs greyish; legs brown-streaked. Underside uniform brown.

Exp. $1 \frac{3}{3}$ inch.

Hab. Shanghai. In coll. W. B. Pryer.

Allied to S. nitens, which is also found in North China. 


\section{Fam. Drepanulidæ.}

\section{Drepana japonica.}

Upperside pale vinous lavender-grey; two narrow brownbordered, yellow, obliquely transverse bands on both wings, the outer band crossing from apex to middle of abdominal margin, the inner band from middle of costa to one third the latter; costal edge and apex of fore wing ochreous yellow; cilia bordered with an inner brown line; a slight curved brown streak on fore wing and a small spot on hind wing at the end of the cell. Prothorax, tip of abdomen, and a band near its base ochreous yellow. Antennæ and front of head, and legs above, brown. Underside pale brownish ochreous, darkest on fore wing.

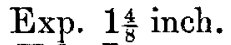

Hab. Japan. In coll. W. B. Pryer.

\section{Fam. Cossidæ.}

\section{Phassus sinensis.}

Male and female. Upperside pale vinous greyish brown: fore wing with pale-bordered blackish spots on the costa; a triangular blackish-brown patch from base of cell extending beneath and broadly to its end, which is marked at the base by a bright yellow spot, and at the end by an oblique straight broad yellow streak and a few speckles; streaks on hind margin and discal and marginal band composed of grey chalybeate streaks between the reins, the transverse interspaces brown: hind wing paler and slightly diaphanous, apical border with chalybeate streaks. Underside paler, markings indistinct.

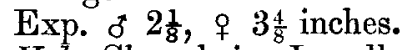

Hab. Shanghai. In coll. W. B. Pryer and F. Moore.

XIII.-Description of four new Species of Birds from the Indian Region. By ARTHur, Marquis of TwEeddale, F.R.S.

\section{Megalurus ruficeps, sp. $\mathrm{n}$.}

․ Lower surface white, faintly tinged with cream-colour on the breast. Flanks pale earthy brown. Under tail-coverts pale dingy isabelline rufous; thigh-coverts of a more decided 